\title{
Agroecological justification of winter wheat fertilization systems in the south-west of the Central Black-soil region
}

\author{
Sergey Tyutyunov ${ }^{1}$, Pavel Solntsev ${ }^{1}$, Alexey Stupakov ${ }^{2, *}$, Marina Kulikova ${ }^{2}$, and $\mathrm{Al}$ \\ Dhuhaibawi Haider Khalaf $^{2}$ \\ ${ }^{1}$ FSBSU "Belgorod FASC RAS", Belgorod, Russia \\ ${ }^{2}$ FSBEU "Belgorod SAU", 1, Vavilova Str., Office 306, 308503, Mayskiy, Belgorod, Russia
}

\begin{abstract}
Under the conditions of the south-western part of the Central Black-soil region in the grain-and-plant crop rotation on the black-soil the typical maximum yield of winter wheat was $5.52 \mathrm{t} / \mathrm{ha}$ when using the organic-mineral fertilizer system as part of mineral fertilizers in the dose of N60P60K60 and manure in the dose of $40 \mathrm{t} / \mathrm{ha}$ according to the third level of plant protection (seed etching of herbicide fungicide insecticide growth substances) with maximum payback of $1 \mathrm{~kg}$ of mineral fertilizers with grain harvest increase $-15.5 \mathrm{~kg}$. Yield increase at the 1 st level of plant protection (seed etching) was $1.86 \mathrm{t} / \mathrm{ha}(68.1 \%)$, at the $2 \mathrm{nd}$ level of protection (seed etching of herbicide fungicide) $-2.55 \mathrm{t} / \mathrm{ha}(93.4 \%)$ and at the $3 \mathrm{rd}$ level of protection $-2.79 \mathrm{t} / \mathrm{ha}(102.2 \%)$. The highest increase from pesticides was 0.69 and $0.93 \mathrm{t} / \mathrm{ha}$ (15.0 and $20.3 \%)$, respectively. The use of such a fertilizer system is justified, in which the energy coefficient was 1.03 and 1.05 . The design of an organic fertilizer system using manure does not meet the requirements of bioenergy efficiency at all levels of plant protection $(\mathrm{Kee}=0.79-0.87)$.
\end{abstract}

\section{Introduction}

Relevance. At present, with the growing economic and environmental problems of the modern state of agriculture of our country, there is a need for large-scale improvement of winter wheat cultivation technologies, as its potential is not fully realized $[1,2,10,14]$. In this regard, the production of high grain yields is mainly ensured by an optimal combination of plant protection agents $[13,8,3]$, the use of mineral $[7,11,15]$ and organic fertilizers [9], as well as the use of an organic-mineral fertilizer system [5, 6]. Agricultural enterprises are offered biological and biological technologies using all types of organic fertilizers in combination with a system of protection of culture [12, 5, 4]. However, data from previous studies need to be refined in a given soil-climate zone.

The research aimed at agroecological justification of winter wheat cultivation technologies based on a combination of fertilizer systems and plant protection levels in the south-western part of the CBR.

\footnotetext{
* Corresponding author: alex.stupackow@yandex.ru
} 
The research has addressed the following challenges:

1. To study the regularity of the effect of fertilization systems on the dynamics of the content of movable forms of food elements in black-soil typical;

2. Determine the effect of fertilizer systems on the clogging of winter wheat crops depending on plant protection levels;

3. To establish the nature of the influence of the complex of agricultural techniques on the yield and quality of winter wheat grain;

4. Carry out an analysis of the bioenergy efficiency of fertilizers depending on the levels of plant protection.

The scientific novelty is that for the first time in the Central Black-soil region, a comprehensive assessment of the different intensity of winter wheat cultivation technologies based on a combination of fertilization and plant protection systems has been carried out in a long-term stationary experience. The influence of various technologies of winter wheat cultivation on nutritional regime, crop clogging, grain yield and quality, crop structure is shown.

The practical significance of the work is that the results of the carried out studies can be used in the development of technologies for the cultivation of winter wheat, in which, on the basis of a combination of the most important agricultural techniques - fertilization and plant protection systems - are combined into a single whole principles of increasing the productivity of ration, environmental protection and resource saving.

Growing winter wheat according to these technologies allows, on the basis of constant monitoring of the content of food elements in the soil and control of energy consumption per unit of production, to increase soil fertility, increase the yield of winter wheat grain and increase its quality.

\section{Meteorological conditions of the study period}

According to the amount of atmospheric precipitation, the territory of the experimental field of FSBSU "Belgorod FASC RAS", where the research was carried out, belongs to the zone of moderate moisturization. The average annual rainfall recorded by the Race weather station was $553 \mathrm{~mm}$ as of 2019 . On average, precipitation fell by $57.2 \mathrm{~mm}$ or $10.3 \%$ of the average summer values in two agricultural years.

The largest number fell in 2017/2018 agricultural year: the excess was $301.8 \mathrm{~mm}$ or $54.6 \%$ of the average multi-year values, and during the spring-summer vegetation period April-July - $166.2 \mathrm{~mm}$ or $75.5 \%$. The most rainy was July, when 3.6 monthly rates $(247.4$ $\mathrm{mm}$ ) fell.

In the 2018/2019 agricultural year, there was a precipitation deficit of $147.4 \mathrm{~mm}$ or $27.7 \%$. In the period April-July the deficit was less $-40.7 \mathrm{~mm}$ or $18.5 \%$. The most arid was June, when $12.5 \mathrm{~mm}$ of precipitation or $19.8 \%$ of the norm fell.

The average daily air temperature during the study years exceeded the average multiyear values by $3.6^{\circ} \mathrm{C}$.

The excess in the $2017 / 2018$ agricultural year was $3.5^{\circ} \mathrm{C}$, and in the 2018/2019 agricultural year $3.8^{\circ} \mathrm{C}$. At April-July average multi-year values of $15.0^{\circ} \mathrm{C}$, the air temperature was higher by 3.8 and $3.7^{\circ} \mathrm{C}$, respectively. The largest increase was in May $2018\left(5.8^{\circ} \mathrm{C}\right)$ and June $2019\left(6.6^{\circ} \mathrm{C}\right)$.

The hydrothermal coefficient (HTC according to Selyaninov) was 1.69 and 0.79 respectively over the years, with an average of 1.03 . 


\section{Methodology of research}

Comprehensive studies on the studied topic were carried out on the experimental field of FSBSU "Belgorodsky FASC RAS" in a long-term field stationary experience in grainbased 5-Polish crop rotation with such rotation: black steam, winter wheat, sugar beet, barley, corn per grain.

The soil of the test site is the black-soil of a typical heavy carbon granulometric composition with humus content of 4.5-5.0\%, sum of absorbed bases 37-40 mg-eq./100 g of soil, hydrolytic acidity of soil 1.6-1.8 mg-eq./100 $\mathrm{g}$ of soil, $\mathrm{pH}_{\mathrm{KCl}} 5.8-5.9$ and content of movable phosphorus and exchange potassium (according to Chirikov), respectively, 55-60 and $105-125 \mathrm{mg} / \mathrm{kg}$ of soil.

The experience is laid down in 3 -fold repetition by the method of split divisions. The effect and interaction of various combinations of two factors of technological techniques, including the 4 fertilizer system and the 3 plant protection system were studied. Ploughing to a depth of 20-22 cm was used as the main soil treatment method.

Experience diagram with fertilizers:

1) control (without fertilizers);

2) $\mathrm{N}_{60} \mathrm{P}_{60} \mathrm{~K}_{60}$;

3) manure 40 t/ha - background;

4) background $+\mathrm{N}_{60} \mathrm{P}_{60} \mathrm{~K}_{60}$.

The plant protection system had 3 levels:

1) seed etching (Dospeh 3, KS - 0.50 1/t Tabu, FRS - 0.50 1/t seeds);

2) the same as 1 herbicides (in the cutting phase) Asterix, SE - 0.60 1/ha fungicide (in the piping phase) Alcor Super, CE - 0.50 1/ha.

3) same as 2 Clonrin insecticide, CE - 0.20 1/ha Nowil, RE - 0.03 1/ha.

Mineral fertilizers (an azofoska 16:16:16) brought on allotments manually, the semirerotting manure of cattle - a navozorazbrasyvatel, means of protection of plants - the OP2000 sprayer.

The winter wheat variety Synthetic, zoned in the region, was sown.

The methodological basis of the studies carried out was a field experiment. The research was guided by generally accepted methods, according to which the following observations and calculations were carried out:

- Agrometeorological indicators were recorded on the weather bridge located on the territory of the experimental field of FSBSU "Belgorod FASC RAS" in accordance with the "Manual for agrometeorological posts";

- during vegetation of a winter wheat determined content in the soil of nitrate nitrogen (Russian Standard 26488-85), mobile phosphorus and exchange potassium on Chirikova (Russian Standard 26204-91), soil samples selected during shoots and during harvesting of a winter wheat in layers of earth $0-10,10-20,20-30 \mathrm{~cm}$;

- Taking into account the clogging of winter wheat crops was carried out in two terms by quantitative-weight method according to the method of VISR (1990). The first count is before treatment with herbicide, the second count is 30 days after treatment;

- In the phase of complete ripeness of winter wheat, snoop samples were taken to determine the structure of the crop (height of plants, total number of stems, number of productive stems, weight of grain from one colos);

- The harvest was carried out with the help of Sampo-500 combine by method of continuous harvesting of the recorded area of the lessons of experience;

- The resulting yield was calculated by $100 \%$ purity and $14 \%$ humidity.

From each repetition of the test, grain samples were taken to determine humidity (Russian Standard 13586.5), percentage of weed impurity (Russian Standard 30483-97), 
mass of 1000 grains (Russian Standard 10842-89), nature of grain (Russian Standard 10840-64);

- Statistical processing of the obtained data was carried out by dispersion analysis using computer programs (NIRSMAIN, Microsoft Offis Excel 2010).

\section{Discussion of the received results. Impact of fertilizers and plant protection on the content of. In soil of movable forms of food elements}

Analysis of nitrate content during seeding showed that the most significant increase in soil layers 0-10 and 10-20 cm was observed when mineral fertilizers were applied under winter wheat in the dose of $\mathrm{N} 60 \mathrm{P} 60 \mathrm{~K} 60$, as well as the combination of $\mathrm{N}_{60} \mathrm{P}_{60} \mathrm{~K}_{60}$ with manure in the dose of $40 \mathrm{t} /$ ha (table 1 ).

Table 1. Effect of fertilizers on nitrate nitrogen, mobile phosphorus and exchange potassium content in soil under winter wheat, $\mathrm{mg} / \mathrm{kg}$ soil (average for plant protection levels, 2018-2019).

\begin{tabular}{|c|c|c|c|c|c|}
\hline \multirow{2}{*}{$\begin{array}{c}\text { Fertilizer } \\
\text { element }\end{array}$} & \multirow{2}{*}{$\begin{array}{c}\text { Layers } \\
\text { Soils, } \\
\text { Cm } \\
\end{array}$} & \multicolumn{4}{|c|}{ Experience options } \\
\hline & & $\begin{array}{c}\text { Without } \\
\text { Fertilizers }\end{array}$ & $\mathbf{N}_{60} \mathbf{P}_{60} K_{60}$ & $\begin{array}{c}\text { Manure } 40 \text { t/ha - } \\
\text { background }\end{array}$ & $\begin{array}{c}\text { Background + } \\
\mathbf{N}_{60} \mathbf{P}_{60} \mathbf{K}_{60}\end{array}$ \\
\hline \multicolumn{6}{|c|}{ Period of shoots } \\
\hline \multirow{5}{*}{$\mathrm{NO}_{3}$} & $0-10$ & 9.25 & 11.65 & 9.65 & 12.68 \\
\hline & $10-20$ & 8.33 & 10.47 & 8.98 & 11.37 \\
\hline & $20-30$ & 7.20 & 8.43 & 8.43 & 9.62 \\
\hline & $0-30$ & 8.26 & 10.26 & 9.02 & 11.22 \\
\hline & $\mathrm{LED}_{05}$ & \multicolumn{4}{|c|}{0.3} \\
\hline \multirow{5}{*}{$\mathrm{P}_{2} \mathrm{O}_{5}$} & $0-10$ & 62.7 & 123.7 & 64.7 & 124.3 \\
\hline & $10-20$ & 55.0 & 104.3 & 57.7 & 107.0 \\
\hline & $20-30$ & 50.3 & 95.3 & 52.7 & 103.7 \\
\hline & $0-30$ & 56.0 & 107.8 & 58.3 & 111.7 \\
\hline & $\mathrm{LED}_{05}$ & \multicolumn{4}{|c|}{8.6} \\
\hline \multirow{5}{*}{$\mathrm{K}_{2} \mathrm{O}$} & $0-10$ & 108.3 & 126.3 & 112.7 & 138.3 \\
\hline & $10-20$ & 104.3 & 119.7 & 108.0 & 128.0 \\
\hline & $20-30$ & 100.7 & 104.3 & 103.0 & 106.7 \\
\hline & $0-30$ & 104.4 & 116.8 & 107.9 & 124.3 \\
\hline & $\mathrm{LED}_{05}$ & \multicolumn{4}{|c|}{10.4} \\
\hline \multicolumn{6}{|c|}{ Harvesting period } \\
\hline \multirow{5}{*}{$\mathrm{NO}_{3}$} & $0-10$ & 3.63 & 4.80 & 4.13 & 6.07 \\
\hline & $10-20$ & 3.20 & 4.37 & 3.43 & 5.33 \\
\hline & $20-30$ & 2.73 & 3.82 & 2.93 & 4.43 \\
\hline & $0-30$ & 3.19 & 4.33 & 3.50 & 5.28 \\
\hline & $\mathrm{LED}_{05}$ & \multicolumn{4}{|c|}{0.3} \\
\hline \multirow{5}{*}{$\mathrm{P}_{2} \mathrm{O}_{5}$} & $0-10$ & 56.8 & 114.7 & 62.3 & 117.7 \\
\hline & $10-20$ & 51.2 & 106.0 & 57.0 & 106.3 \\
\hline & $20-30$ & 44.7 & 95.0 & 52.7 & 96.3 \\
\hline & $0-30$ & 50.9 & 105.2 & 57.3 & 106.8 \\
\hline & $\mathrm{LED}_{05}$ & \multicolumn{4}{|c|}{8.6} \\
\hline
\end{tabular}




\begin{tabular}{|c|c|c|c|c|c|}
\hline \multirow{4}{*}{$\mathrm{K}_{2} \mathrm{O}$} & $0-10$ & 102.3 & 126.7 & 106.0 & 136.0 \\
\cline { 2 - 6 } & $10-20$ & 97.7 & 106.3 & 99.7 & 122.0 \\
\cline { 2 - 6 } & $20-30$ & 90.7 & 100.7 & 94.0 & 109.0 \\
\cline { 2 - 6 } & $0-30$ & 96.9 & 111.2 & 99.9 & 122.3 \\
\cline { 2 - 6 } & $\mathrm{LED}_{05}$ & \multicolumn{4}{|c|}{10.4} \\
\hline
\end{tabular}

In the layer $20-30 \mathrm{~cm}$ variation of nitrate content depending on fertilizers is less significant. Only $40 \mathrm{t} / \mathrm{ha}$ of manure resulted in the lowest increase in manure content.

By the harvest period there was a decrease in nitrate content in the soil, and the most noticeable - in the layer $0-10 \mathrm{~cm}$ when growing winter wheat with mineral fertilizers $(-6.85$ $\mathrm{mg} / \mathrm{kg}$ of soil) and their combination with manure $(-6.61 \mathrm{mg} / \mathrm{kg})$.

Patterns of the effect of fertilizers on the content of this food element in the soil, noted for the period of seedlings, were also evident during the harvest period. A characteristic feature for both terms of determination is a marked decrease in content with depth of the soil horizon.

The maximum nitrate content noted in the studies - $12.68 \mathrm{mg} / \mathrm{kg}$ - is well below the level MPC in soil by $\mathrm{NO}_{3}-130 \mathrm{mg} / \mathrm{kg}$ (Hygienic Standards GN 2.1.7.2041-06, No. CAS 14797-55-8) and cannot pose a danger to plants, animals and humans.

Changes in mobile phosphate content in soil are more significant than variations in nitrate content. Thus, the increase in phosphate content when using mineral fertilizers in the dose of $\mathrm{N}_{60} \mathrm{P}_{60} \mathrm{~K}_{60}$ and the combination of $\mathrm{N}_{60} \mathrm{P}_{60} \mathrm{~K}_{60}$ with manure in the dose of $40 \mathrm{t} / \mathrm{ha}$ was $0-10 \mathrm{~cm}$ in the soil layer for the period of winter wheat seeding 61.0 and $61.6 \mathrm{mg} / \mathrm{kg}(97.3-$ $98.2 \%)$, respectively, and nitrate content 2.40 and $3.43 \mathrm{mg} / \mathrm{kg}(26.0$ and $37.1 \%)$.

The decrease in phosphate content in this soil layer in absolute values (- 9.0 and - 6.6 $\mathrm{mg} / \mathrm{kg})$ is equivalent to the decrease in nitrate content $(-6.85$ and $-6.61 \mathrm{mg} / \mathrm{kg})$, but in relative values is less significant $(7.3 \%$ and $5.3 \%)$ than the decrease in nitrate content $(58.8$ and $52.1 \%$ ).

The use of $40 \mathrm{t} / \mathrm{ha}$ of manure alone contributed to the lowest increase in phosphate content in the soil.

The patterns associated with changes in the content of metabolic potassium influenced by fertilizers are similar to those noted for phosphates and to a lesser extent for nitrates. The maximum increase in its content was marked by the use of the organic-mineral fertilizer system when it amounted to $30.0 \mathrm{mg} / \mathrm{kg}(27.7 \%)$ in the upper $0-10 \mathrm{~cm}$ soil layer for the period of culture seeding.

In the mineral system growth is slightly lower $-18.0 \mathrm{mg} / \mathrm{kg}(16.6 \%)$, and the smallest in the organic system $-4.4 \mathrm{mg} / \mathrm{kg}(4.1 \%)$, which is unreliable $\left(\mathrm{LED}_{05}=10.4 \mathrm{mg} / \mathrm{kg}\right)$.

The intensity of the decrease in the content of exchange potassium during the "seedling - harvesting" period is even lower than that of phosphates and it was observed only in soil without fertilizers - by $6.0 \mathrm{mg} / \mathrm{kg}(16.7 \%)$ and in the case of manure - by $6.7 \mathrm{mg} / \mathrm{kg}$ $(14.9 \%)$. Moreover, these changes are unreliable, which indicate a tendency to decrease potassium content during the period of active plant vegetation.

\section{Impact of fertilizers and plant protection on clogging of winter wheat crops}

Analysis of the clogging of winter wheat crops revealed that seed etching before sowing (Dospeh 3, KS - $0.50 \mathrm{l} / \mathrm{t}$ Tabu, FRS - $0.50 \mathrm{l} / \mathrm{t}$ seeds) caused a decrease in clogging within $4.2-16.3 \%$ during the period of active spring-summer vegetation (Table 2 ).

At the same time, the more intense decline in the number of segetal vegetation was provided by fertilizers used to improve the growth and development of culture. 
Application of mineral fertilizers in the dose of $\mathrm{N}_{60} \mathrm{P}_{60} \mathrm{~K}_{60}$ contributed to maximum reduction of clogging - by $16.3 \%$, their combination with 40 t/ha manure - by $10.0 \%$, application of only $40 \mathrm{t} / \mathrm{ha}$ manure - by $7.4 \%$, while in crops without fertilizers it decreased by only $4.2 \%$.

Obviously, seed etching in combination with fertilisers formed high immune properties of winter wheat, and more developed plants showed increased competition against weeds. Fertilizers in mineral, organic and organo-mineral systems provided increase of herbicide application efficiency from $83.9-85.7 \%$ at cultivation of winter wheat without fertilizers up to $88.5-92.6 \%$ at their use.

Studies have also found that herbicides in combination with fungicides (level 2 protection), as well as insecticides and growth substances (level 3 protection), which were previously used for other crops in crop rotation, formed agrocenosis with significantly fewer segetal plants, as evidenced by their number before herbicide treatment.

The reduction of clogging relative to the variant where only seed etching was carried out was 35.4 and $41.7 \%$ in winter wheat crops without fertilizers, respectively, 39.5 and $44.2 \%$ in fertilizer mineral system, 29.6 and $33.3 \%$ in fertilizer organic system and 34.0 and $46.0 \%$ in organic mineral system.

Table 2. Impact of fertilizers and plant protection on the clogging of winter wheat crops (2018-2019).

\begin{tabular}{|c|c|c|c|c|c|}
\hline \multicolumn{2}{|c|}{ Experience options } & \multicolumn{2}{|c|}{ Quantity of weeds, piece/sq.m } & \multicolumn{2}{|c|}{ Decrease in contaminatior } \\
\hline $\begin{array}{c}\text { Fertiliz } \\
\text { ers }\end{array}$ & $\begin{array}{l}\text { Protection } \\
\text { levels }\end{array}$ & $\begin{array}{c}\text { Before } \\
\text { processing }\end{array}$ & After 30 days & Piece/sq.m & $\%$ \\
\hline \multirow{3}{*}{$\begin{array}{l}\text { without } \\
\text { fertilize } \\
\text { rs }\end{array}$} & $1^{*}$ & 48 & 46 & 2 & 4.2 \\
\hline & 2 & 31 & 5 & 26 & 83.9 \\
\hline & 3 & 28 & 4 & 24 & 85.7 \\
\hline \multirow{3}{*}{$\begin{array}{c}\mathrm{N}_{60} \mathrm{P}_{60} \\
\mathrm{~K}_{60}\end{array}$} & 1 & 43 & 36 & 7 & 16.3 \\
\hline & 2 & 26 & 3 & 23 & 88.5 \\
\hline & 3 & 24 & 2 & 22 & 91.7 \\
\hline \multirow{3}{*}{$\begin{array}{c}\text { manure } \\
40 \text { t/ha } \\
- \\
\text { backgro } \\
\text { und }\end{array}$} & 1 & 54 & 50 & 4 & 7.4 \\
\hline & 2 & 38 & 4 & 34 & 89.5 \\
\hline & 3 & 36 & 3 & 33 & 91.7 \\
\hline \multirow{3}{*}{$\begin{array}{c}\text { backgro } \\
\text { und }+ \\
+\mathrm{N}_{60} \mathrm{P}_{60} \\
\mathrm{~K}_{60}\end{array}$} & 1 & 50 & 45 & 5 & 10.0 \\
\hline & 2 & 33 & 3 & 30 & 90.9 \\
\hline & 3 & 27 & 2 & 25 & 92.6 \\
\hline \multicolumn{2}{|c|}{$\mathrm{LED}_{05}$, piece/sq.m } & \multicolumn{3}{|c|}{6} & - \\
\hline
\end{tabular}

* Note. Plant protection levels: 1 - seed etching; 2 - is the same as $1+$ herbicide + fungicides; 3 - same as $2+$ insecticides + growth substances.

\section{Impact of fertilizers and plant protection on winter wheat grain yield}

The effectiveness of fertilizers and pesticides on winter wheat was dependent on different weather conditions. 
In 2018, grain yields were higher (table 3) than in 2019 (table 4), but increases from mineral fertilizers are lower and from pesticides are higher.

The efficiency of manure in more arid - 2019 - is markedly less. This is due to higher moisture availability in the 2017/2018 agricultural year than in the compared one with roughly the same heat availability.

The payback of mineral fertilizers additional products, therefore, above only in the mineral system of fertilizer in 2019 which made $9.9 \mathrm{~kg} / \mathrm{kg}$ and was $1.2 \mathrm{~kg} / \mathrm{kg}$ higher or for $12.1 \%$ in comparison with 2018.

Table 3. Impact of fertilizers and plant protection products on winter wheat yield in 2018 .

\begin{tabular}{|c|c|c|c|c|c|c|c|c|c|}
\hline \multicolumn{2}{|c|}{ Experience options } & \multirow{3}{*}{$\begin{array}{c}\text { Produc } \\
\text { Tivity, } \\
\text { t/ha }\end{array}$} & \multicolumn{6}{|c|}{ Productivity increase from: } & \multirow{3}{*}{$\begin{array}{c}\text { Average } \\
\text { return } \\
1 \mathrm{~kg} \mathrm{NPK}, \\
\mathrm{kg}\end{array}$} \\
\hline \multirow[t]{2}{*}{ Fertilizers } & \multirow[t]{2}{*}{$\begin{array}{c}\text { Protec } \\
\text { Tion levels }\end{array}$} & & \multicolumn{2}{|c|}{ Fertilizers } & \multicolumn{2}{|c|}{$\begin{array}{c}\text { Fertilizers } \\
+ \\
\text { Pesticides } \\
\end{array}$} & \multicolumn{2}{|c|}{ Pesticides } & \\
\hline & & & $\mathrm{t} / \mathrm{ha}$ & $\%$ & $\mathrm{t} / \mathrm{ha}$ & $\%$ & $\mathrm{t} / \mathrm{ha}$ & $\%$ & \\
\hline \multirow{3}{*}{$\begin{array}{l}\text { without } \\
\text { fertilizers }\end{array}$} & $1^{*}$ & 3.12 & - & - & - & - & - & - & - \\
\hline & 2 & 3.39 & - & - & - & - & 0.27 & 8.7 & - \\
\hline & 3 & 3.45 & - & - & - & - & 0.33 & 10.6 & - \\
\hline \multirow{3}{*}{$\mathrm{N}_{60} \mathrm{P}_{60} \mathrm{~K}_{60}$} & 1 & 4.69 & 1.57 & 50.3 & - & - & - & - & 8.7 \\
\hline & 2 & 5.47 & 2.08 & 61.4 & 2.35 & 75.3 & 0.78 & 16.6 & 13.1 \\
\hline & 3 & 5.60 & 2.15 & 62.3 & 2.48 & 79.5 & 0.91 & 19.4 & 13.8 \\
\hline \multirow{3}{*}{$\begin{array}{c}\text { manure } 40 \\
\text { t/ha - } \\
\text { background }\end{array}$} & 1 & 4.44 & 1.32 & 42.3 & - & - & - & - & - \\
\hline & 2 & 4.98 & 1.59 & 46.9 & 1.86 & 59.6 & 0.54 & 12.2 & - \\
\hline & 3 & 5.22 & 1.77 & 51.3 & 2.10 & 67.3 & 0.78 & 17.6 & - \\
\hline \multirow{3}{*}{$\begin{array}{l}\text { background } \\
++\mathrm{N}_{60} \mathrm{P}_{60} \mathrm{~K}_{60}\end{array}$} & 1 & 4.94 & 1.82 & 58.3 & - & - & - & - & 10.1 \\
\hline & 2 & 5.74 & 2.35 & 69.3 & 2.62 & 84.0 & 0.80 & 16.2 & 14.6 \\
\hline & 3 & 5.92 & 2.47 & 71.6 & 2.80 & 89.7 & 0.98 & 19.8 & 15.6 \\
\hline \multicolumn{2}{|c|}{$\mathrm{LED}_{05}$} & 0.35 & \\
\hline
\end{tabular}

* Note. Plant protection levels: 1 - seed etching; 2 - is the same as $1+$ herbicide + fungicides; 3 - same as $2+$ insecticides + growth substances.

With the combination of fertilizers with pesticides, due to the different direction of effects from their use depending on weather conditions, the payback of mineral fertilizers changed little.

On average, in 2018-2019, the maximum yield of winter wheat was $5.52 \mathrm{t} / \mathrm{ha}$ according to the third level of plant protection, in which the whole complex of chemical agents was used: mineral fertilizers, manure, seed etching, herbicides, fungicides, insecticides, growth substances (table 5). The payback of $1 \mathrm{~kg}$ of mineral fertilizers by increasing the harvest here was the largest $-15.5 \mathrm{~kg}$.

The productivity increase from joint effect of mineral fertilizers in a dose of $\mathrm{N}_{60} \mathrm{P}_{60} \mathrm{~K}_{60}$ and manure in a dose of $40 \mathrm{t} / \mathrm{ha}$ at the 1 st level of protection of plants (a treatment of seeds) made $1.86 \mathrm{t} / \mathrm{ha}(68.1 \%$ ), at the $2 \mathrm{nd}$ level of protection (a treatment a seed herbicides fungicides) $-2.55 \mathrm{t} / \mathrm{ha}(93.4 \%$ ) and at the $3 \mathrm{rd}$ level of protection (a treatment a seed herbicides fungicides insecticides growth substances) $-2.79 \mathrm{t} / \mathrm{ha}(102.2 \%)$. 
A slightly smaller increase in the yield of winter wheat grain was observed at a dose of $\mathrm{N}_{60} \mathrm{P}_{60} \mathrm{~K}_{60}-1.68 \mathrm{t} / \mathrm{ha}(64.5 \%)$ at the 1 st level of protection, with 2 and 3 levels of increase being 2.28 and $2.47 \mathrm{t} / \mathrm{ha}(83.5$ and $90.5 \%)$, respectively.

At the same time the payback of mineral fertilizers considerably increased from the $1 \mathrm{st}$ level to the 2nd and 3rd respectively from 9.3 to 12.6 and $13.7 \mathrm{~kg} / \mathrm{kg}(35.5$ and $47.3 \%)$. The lowest yield increase was provided by manure at a dose of $40 \mathrm{t} / \mathrm{ha}-1.09 \mathrm{t} / \mathrm{ha}(39.9 \%)$ at the 1 st level of plant protection. At the $2 \mathrm{nd}$ and $3 \mathrm{rd}$ levels, it increased by 1.53 and $1.74 \mathrm{t} / \mathrm{ha}$ (56.0 and 63.7\%), respectively.

Table 4. Impact of fertilizers and plant protection products on winter wheat yield in 2019.

\begin{tabular}{|c|c|c|c|c|c|c|c|c|c|}
\hline \multicolumn{2}{|c|}{ Experience options } & \multirow{3}{*}{$\begin{array}{l}\text { Producti } \\
\text { Vity, } \\
\text { t/ha }\end{array}$} & \multicolumn{6}{|c|}{ Productivity increase from: } & \multirow{3}{*}{$\begin{array}{c}\text { Average } \\
\text { return } \\
1 \text { kg NPK, } \\
\text { kg }\end{array}$} \\
\hline \multirow[t]{2}{*}{ Fertilizers } & \multirow{2}{*}{$\begin{array}{c}\text { Pro } \\
\text { Tec } \\
\text { Tion levels }\end{array}$} & & \multicolumn{2}{|c|}{ Fertilizers } & \multicolumn{2}{|c|}{$\begin{array}{c}\text { Fertilizers } \\
+ \\
\text { Pesticides } \\
\end{array}$} & \multicolumn{2}{|c|}{ Pesticides } & \\
\hline & & & $\mathrm{t} / \mathrm{ha}$ & $\%$ & $\mathrm{t} / \mathrm{ha}$ & $\%$ & $\mathrm{t} / \mathrm{ha}$ & $\%$ & \\
\hline \multirow{3}{*}{$\begin{array}{l}\text { without } \\
\text { fertilizers }\end{array}$} & $1^{*}$ & 2.34 & - & - & - & - & - & - & - \\
\hline & 2 & 2.54 & - & - & - & - & 0.20 & 8.5 & - \\
\hline & 3 & 2.73 & - & - & - & - & 0.39 & 16.7 & - \\
\hline \multirow{3}{*}{${ }^{.} \mathrm{N}_{60} \mathrm{P}_{60} \mathrm{~K}_{60}$} & 1 & 4.13 & 1.79 & 76.5 & - & - & - & - & 9.9 \\
\hline & 2 & 4.54 & 2.00 & 78.7 & 2.20 & 94.0 & 0.41 & 9.9 & 12.2 \\
\hline & 3 & 4.79 & 2.06 & 75.5 & 2.45 & 104.7 & 0.66 & 16.0 & 13.6 \\
\hline \multirow{3}{*}{$\begin{array}{c}\text { manure } 40 \\
\text { t/ha - } \\
\text { background }\end{array}$} & 1 & 3.19 & 0.85 & 36.3 & - & - & - & - & - \\
\hline & 2 & 3.53 & 0.99 & 39.0 & 1.19 & 50.9 & 0.34 & 10.7 & - \\
\hline & 3 & 3.72 & 0.99 & 36.3 & 1.38 & 59.0 & 0.53 & 16.6 & - \\
\hline \multirow{3}{*}{$\begin{array}{c}\text { background } \\
+ \\
+\mathrm{N}_{60} \mathrm{P}_{60} \mathrm{~K}_{60}\end{array}$} & 1 & 4.24 & 1.90 & 81.2 & - & - & - & - & 10.6 \\
\hline & 2 & 4.82 & 2.28 & 89.8 & 2.48 & 106.0 & 0.58 & 13.7 & 13.8 \\
\hline & 3 & 5.11 & 2.38 & 87.2 & 2.77 & 118.4 & 0.87 & 20.5 & 15.4 \\
\hline \multicolumn{2}{|c|}{$\mathrm{LED}_{05}$} & 0.24 & \\
\hline
\end{tabular}

* Note. Plant protection levels: 1 - seed etching; 2 - is the same as $1+$ herbicide + fungicides; 3 - same as $2+$ insecticides + growth substances.

The highest increase from pesticides at the 2 nd and 3 rd levels of protection in the organic-mineral fertilizer system, respectively, was 0.69 and $0.93 \mathrm{t} / \mathrm{ha}$ (15.0 and $20.3 \%$ ). The mineral fertilizer system contributed to an increase in grain yields from the $2 \mathrm{nd}$ and $3 \mathrm{rd}$ level of protection with the use of pesticides by 0.60 and $0.79 \mathrm{t} / \mathrm{ha}(13.6$ and $17.9 \%)$, respectively, and organic by 0.44 and $0.65 \mathrm{t} / \mathrm{ha}$ (11.5 and $17.0 \%)$.

Organic-mineral fertilizer system to a greater extent than other systems provided a tendency to increase grain nature (13-16 g/l). Mineral system showed almost the same result (12-15 g/l), and organic - slightly less (10-14 g/l). The dependence of nature on plant protection systems is less pronounced (table 6 ).

Fertilizer systems have contributed to a reliable increase in the gluten content of winter wheat grains. In terms of increasing content of its fertilizer system, the following descending series is located: organo-mineral (3.8-5.3\%), mineral (2.6-3.3\%) and organic $(2.1-2.5 \%)$.

A significant increase depending on plant protection systems (1.5\%) was observed in the transition from the 1 st level of protection to the $3 \mathrm{rd}$ level, that is, the whole complex of 
pesticides used during the spring-summer vegetation of winter wheat was added to seed etching: herbicides, fungicides, insecticides, growth substances.

\section{Impact of fertilizers and plant protection for winter wheat grain quality}

The most significant increase in raw protein content in grain is due to the use of mineral fertilizer system $(2.0 \%)$. The organo-mineral system contributed to its growth by $1.4 \%$.

Table 5. Impact of fertilizers and plant protection on the yield of winter wheat, average for 20182019.

\begin{tabular}{|c|c|c|c|c|c|c|c|c|c|}
\hline \multicolumn{2}{|c|}{ Experience options } & \multirow{3}{*}{$\begin{array}{c}\text { Produc } \\
\text { Tivity, } \\
\text { t/ha }\end{array}$} & \multicolumn{6}{|c|}{ Productivity increase from: } & \multirow{3}{*}{$\begin{array}{c}\text { Average } \\
\text { return } \\
1 \mathrm{~kg} \\
\text { NPK, } \\
\text { kg }\end{array}$} \\
\hline \multirow{2}{*}{ Fertilizers } & \multirow{2}{*}{$\begin{array}{l}\text { Protection } \\
\text { levels }\end{array}$} & & \multicolumn{2}{|c|}{ Fertilizers } & \multicolumn{2}{|c|}{$\begin{array}{l}\text { Fertilizers + } \\
\text { Pesticides }\end{array}$} & \multicolumn{2}{|c|}{ Pesticides } & \\
\hline & & & T/ha & $\%$ & T/ha & $\%$ & T/ha & $\%$ & \\
\hline \multirow{3}{*}{$\begin{array}{l}\text { Without } \\
\text { fertilizers }\end{array}$} & $1^{*}$ & 2.73 & - & - & - & - & - & - & - \\
\hline & 2 & 2.97 & - & - & - & - & 0.24 & 8.8 & - \\
\hline & 3 & 3.09 & - & - & - & - & 0.36 & 13.2 & - \\
\hline \multirow{3}{*}{$\mathrm{N}_{60} \mathrm{P}_{60} \mathrm{~K}_{60}$} & 1 & 4.41 & 1.68 & 61.5 & - & - & - & - & 9.3 \\
\hline & 2 & 5.01 & 2.04 & 68.7 & 2.28 & 83.5 & 0.60 & 13.6 & 12.6 \\
\hline & 3 & 5.20 & 2.11 & 68.2 & 2.47 & 90.5 & 0.79 & 17.9 & 13.7 \\
\hline \multirow{3}{*}{$\begin{array}{c}\text { Manure } 40 \\
\text { t/ha - } \\
\text { background }\end{array}$} & 1 & 3.82 & 1.09 & 39.9 & - & - & - & - & - \\
\hline & 2 & 4.26 & 1.29 & 43.4 & 1.53 & 56.0 & 0.44 & 11.5 & - \\
\hline & 3 & 4.47 & 1.38 & 44.7 & 1.74 & 63.7 & 0.65 & 17.0 & - \\
\hline \multirow{3}{*}{$\begin{array}{c}\text { Background } \\
+ \\
+\mathrm{N}_{60} \mathrm{P}_{60} \mathrm{~K}_{60}\end{array}$} & 1 & 4.59 & 1.86 & 68.1 & - & - & - & - & 10.3 \\
\hline & 2 & 5.28 & 2.31 & 77.8 & 2.55 & 93.4 & 0.69 & 15.0 & 14.2 \\
\hline & 3 & 5.52 & 2.43 & 78.6 & 2.79 & 102.2 & 0.93 & 20.3 & 15.5 \\
\hline \multicolumn{2}{|c|}{$\mathrm{LED}_{05}$} & 0.30 & \multicolumn{7}{|c|}{-} \\
\hline
\end{tabular}

* Note. Plant protection levels: 1 - seed etching; 2 - is the same as $1+$ herbicide + fungicides; 3 - same as $2+$ insecticides + growth substances.

The effect of the organic system on the change in crude protein content was not evident.

Protein collection, as an integral indicator of yield and quality of production, proved to be almost equal in the application of mineral fertilizer system $-\mathrm{N}_{60} \mathrm{P}_{60} \mathrm{~K}_{60}-643 \mathrm{~kg} / \mathrm{ha}$ and organic-mineral system - $\mathrm{N}_{60} \mathrm{P}_{60} \mathrm{~K}_{60}$ in combination with $40 \mathrm{t} / \mathrm{ha}$ manure $-646 \mathrm{~kg} / \mathrm{ha}$. Growth was 315 and $318 \mathrm{~kg} / \mathrm{ha}(96.0$ and $97.0 \%)$, respectively.

Manure increased protein collection by $132 \mathrm{~kg} / \mathrm{ha}(40.2 \%)$.

\section{Impact of fertilizers and plant protection on winter wheat crop structure}

Observations have shown that fertilizers have contributed to a significant increase in the number of productive winter wheat stems (table 7). The largest amount of them was in the application of organic-mineral fertilizer system with the 3rd level of protection - 462 piece/sq.m. 
With the step-by-step increase in the intensity of protective measures $(1,2,3$ - plant protection levels) in crops without fertilizers, the number of productive stems increased significantly from 331 to 349 and 360 piece/sq.m. A similar pattern was observed as a result of manure application, but at a higher level - from 381 to 398 and 414 piece/sq.m. In mineral and organo-mineral fertiliser systems there is a tendency to increase them at transition from the 1 st to the 2 nd level of protection. And in the organ-mineral system, in addition, during the transition from the 2 nd to the 3 rd level of protection there is a significant increase in them.

Table 6. Impact of fertilizers and plant protection products on winter wheat grain quality (20182019).

\begin{tabular}{|c|c|c|c|c|c|c|c|c|c|}
\hline \multicolumn{2}{|c|}{ Experience options } & \multicolumn{2}{|c|}{ Grain Nature } & \multicolumn{2}{|c|}{ Gluten } & \multicolumn{2}{|c|}{ Crude Protein } & \multicolumn{2}{|c|}{ Whole proteir } \\
\hline Fertilizers & $\begin{array}{c}\text { Prote } \\
\text { ction } \\
\text { levels } \\
\end{array}$ & G/I & $+1-$ & $\%$ & $+/-$ & $\%$ & $+/-$ & Kg/ha & $+/-$ \\
\hline \multirow{3}{*}{$\begin{array}{l}\text { Without } \\
\text { fertilizers }\end{array}$} & $1^{*}$ & 779 & - & 24.0 & - & \multirow{3}{*}{11.2} & \multirow{3}{*}{ - } & \multirow{3}{*}{328} & \multirow{3}{*}{-} \\
\hline & 2 & 785 & 6 & 23.7 & -0.3 & & & & \\
\hline & 3 & 787 & 8 & 24.7 & 0.7 & & & & \\
\hline \multirow{3}{*}{$\mathrm{N}_{60} \mathrm{p}_{60} \mathrm{k}_{60}$} & 1 & 791 & 12 & 26.6 & 2.6 & \multirow{3}{*}{13.2} & \multirow{3}{*}{2.0} & \multirow{3}{*}{643} & \multirow{3}{*}{315} \\
\hline & 2 & 794 & 15 & 26.8 & 2.8 & & & & \\
\hline & 3 & 794 & 15 & 27.3 & 3.3 & & & & \\
\hline \multirow{3}{*}{$\begin{array}{c}\text { Manure } 40 \\
\text { t/ha - } \\
\text { background }\end{array}$} & 1 & 789 & 10 & 26.1 & 2.1 & \multirow{3}{*}{11.0} & \multirow{3}{*}{-0.2} & \multirow{3}{*}{460} & \multirow{3}{*}{132} \\
\hline & 2 & 789 & 10 & 26.2 & 2.2 & & & & \\
\hline & 3 & 793 & 14 & 26.5 & 2.5 & & & & \\
\hline \multirow{3}{*}{$\begin{array}{l}\text { Background } \\
+\mathrm{N}_{60} \mathrm{P}_{60} \mathrm{~K}_{60}\end{array}$} & 1 & 792 & 13 & 27.8 & 3.8 & \multirow{3}{*}{12.6} & \multirow{3}{*}{1.4} & \multirow{3}{*}{646} & \multirow{3}{*}{318} \\
\hline & 2 & 795 & 16 & 28.0 & 4.0 & & & & \\
\hline & 3 & 795 & 16 & 29.3 & 5.3 & & & & \\
\hline \multicolumn{2}{|c|}{$\operatorname{Led}_{05}$} & \multicolumn{2}{|c|}{$\mathrm{F}_{\mathrm{t}}>\mathrm{f}_{05}$} & \multicolumn{2}{|c|}{1.4} & \multicolumn{2}{|c|}{0.6} & \multicolumn{2}{|c|}{49} \\
\hline
\end{tabular}

* Note. Plant protection levels: 1 - seed etching; 2 - is the same as $1+$ herbicide + fungicides; 3 - same as $2+$ insecticides + growth substances.

The height of winter wheat plants increased significantly with the application of mineral fertilizers and their combinations with manure. Manure has led to a tendency to increase it. There is also a tendency to increase when herbicides and fungicides are used in the protection system.

A significant increase in the mass of 1000 grains $\left(\mathrm{LED}_{05}=1.2 \mathrm{~g}\right)$ caused mineral fertilizers in the dose of $\mathrm{N}_{60} \mathrm{P}_{60} \mathrm{~K}_{60}$ using the $3 \mathrm{rd}$ level of plant protection $(1.29 \mathrm{~g})$, but against it the increase in their mass under the influence of fertilizers $(0.71 \mathrm{~g})$ is estimated as a trend. The combined application of mineral fertilizers and manure at a dose of $40 \mathrm{t} / \mathrm{ha}$ contributed to a significant increase in the weight of zeroes at the $2 \mathrm{nd}$ and $3 \mathrm{rd}$ levels of protection (1.44 and $1.48 \mathrm{~g}$, respectively). It has also been found that with each new level of protection in all fertilizer systems there has been a systematic tendency to increase the mass of 1000 grains. 
The weight of grains from one wheel increased significantly when fertilizers were applied in mineral, organic and organo-mineral fertiliser systems. It was greatest at the 2 nd and 3rd levels of protection using mineral and organo-mineral fertiliser systems - 1.11-1.13 g. At the same time, its increase with increasing intensity of protection means application from the 1 st to the 2 nd level is characterized as significant, and from the 2 nd to the 3 rd as a weak trend.

Table 7. Impact of fertilizers and plant protection on winter wheat crop structure (2018-2019).

\begin{tabular}{|c|c|c|c|c|c|}
\hline \multicolumn{2}{|c|}{ Experience options } & \multirow{2}{*}{$\begin{array}{c}\text { Number } \\
\text { Productive } \\
\text { stalks, } \\
\text { Piece/sq.m }\end{array}$} & \multirow{2}{*}{$\begin{array}{c}\text { Height } \\
\text { Plants, } \\
\text { Cm }\end{array}$} & \multirow{2}{*}{$\begin{array}{c}\text { Weight } \\
\text { Is 1000 } \\
\text { grains, } \\
\text { G }\end{array}$} & \multirow{2}{*}{$\begin{array}{c}\text { Weight } \\
\text { Grains } \\
\text { From one } \\
\text { Ear, } \\
\text { G }\end{array}$} \\
\hline Fertilizers & $\begin{array}{c}\text { Protection } \\
\text { levels }\end{array}$ & & & & \\
\hline \multirow{3}{*}{$\begin{array}{l}\text { Without } \\
\text { Fertilizers }\end{array}$} & $1^{*}$ & 331 & 90 & 41.75 & 0.73 \\
\hline & 2 & 349 & 91 & 42.17 & 0.75 \\
\hline & 3 & 360 & 91 & 42.33 & 0.78 \\
\hline \multirow{3}{*}{$\mathrm{N}_{60} \mathrm{P}_{60} \mathrm{~K}_{60}$} & 1 & 431 & 97 & 42.61 & 0.98 \\
\hline & 2 & 439 & 99 & 42.92 & 1.11 \\
\hline & 3 & 438 & 99 & 43.04 & 1.12 \\
\hline \multirow{3}{*}{$\begin{array}{c}\text { Manure } 40 \mathrm{t} / \mathrm{ha} \text { - } \\
\text { background }\end{array}$} & 1 & 381 & 92 & 42.51 & 0.86 \\
\hline & 2 & 398 & 94 & 42.69 & 0.91 \\
\hline & 3 & 414 & 94 & 42.75 & 0.92 \\
\hline \multirow{3}{*}{$\begin{array}{c}\text { Background }+ \\
+\mathrm{N}_{60} \mathrm{P}_{60} \mathrm{~K}_{60}\end{array}$} & 1 & 434 & 99 & 42.92 & 1.00 \\
\hline & 2 & 440 & 101 & 43.19 & 1.12 \\
\hline & 3 & 462 & 101 & 43.23 & 1.13 \\
\hline \multicolumn{2}{|c|}{$\mathrm{LED}_{05}$} & 9.8 & 4.5 & 1.20 & 0.06 \\
\hline
\end{tabular}

** Note. Plant protection levels: 1 - seed etching; 2 - is the same as $1+$ herbicide + fungicides; 3 - same as $2+$ insecticides + growth substances.

\section{Bioenergetic efficiency of fertilizer application}

Bioenergetic efficiency analysis showed that at all levels of protection the use of mineral fertilizers in the dose of N60P60K60 is energetically justified, as the energy included in the crop increase exceeds the energy costs from the use of fertilizers, and the energy coefficient (coefficient energy efficiency, $\mathrm{C}_{\mathrm{ee}}$ ) exceeds 1.0 (table 8). Accordingly, 1, 2 and 3 levels of protection were $1.80,1.81$ and 1.77 , and energy costs per unit grain yield increase were 9161,8149 and $7931 \mathrm{MJ} / \mathrm{t}$. 
Also effective at the 2nd and 3rd levels of plant protection is application of organicmineral fertiliser system $\left(\mathrm{N}_{60} \mathrm{P}_{60} \mathrm{~K}_{60}+\right.$ manure $\left.40 \mathrm{t} / \mathrm{ha}\right)$, where energy coefficient was equal to 1.03 and 1.05. At the $1 \mathrm{st}$ level of protection, it is not effective in terms of bioenergetic analysis because the $\mathrm{C}_{\mathrm{ee}}<1$ is 0.92 .

Application of only manure without herbicides and fungicides does not justify itself, because energy costs from the use of fertilizers are paid for by the energy contained in the crop increase of only $79 \%\left(\mathrm{C}_{\mathrm{ee}}=0.79\right)$.

When herbicides and fungicides were used, the energy associated with manure application was not covered by bioenergy in crop gain $\left(\mathrm{C}_{\mathrm{ee}}=0.85\right)$ at $16295 \mathrm{MJ} / \mathrm{t}$ grain yield gain energy.

The involvement of herbicides, fungicides, insecticides and growth substances in the plant protection system has also prevented a bioenergically sound crop increase when $\mathrm{C}_{\mathrm{ee}}=$ 0.87 .

Therefore, when designing the fertilization system for the planned crop increase, it is necessary to take into account the value of energy consumption on it, which does not exceed $14437 \mathrm{MJ} / \mathrm{t}$ of increase, as if it is exceeded, bioenergetic expediency will not be observed $\left(\mathrm{C}_{\mathrm{ee}}<1\right)$.

Table 8. Bioenergetic efficiency of fertilizer application depending on winter wheat plant protection (2018-2019).

\begin{tabular}{|c|c|c|c|c|c|c|}
\hline \multicolumn{2}{|c|}{ Experience options } & \multirow{2}{*}{$\begin{array}{c}\text { Grain } \\
\text { yield } \\
\text { increases } \\
\text { from } \\
\text { fertilizers, } \\
\text { T/ha } \\
\end{array}$} & \multirow{2}{*}{$\begin{array}{c}\text { Energy } \\
\text { in } \\
\text { increases } \\
\text { from } \\
\text { fertilizer } \\
\text { use, } \\
\text { MJ/ha } \\
\end{array}$} & \multirow{2}{*}{$\begin{array}{c}\text { Energy } \\
\text { consumption } \\
\text { from } \\
\text { fertilizer } \\
\text { application, } \\
\text { MJ/ha }\end{array}$} & \multirow{2}{*}{$\begin{array}{c}\text { Power } \\
\text { Coefficient, } \\
\text { Piece }\end{array}$} & \multirow{2}{*}{$\begin{array}{c}\text { Energy } \\
\text { consumption } \\
\text { MJ/t grain } \\
\text { increase }\end{array}$} \\
\hline Fertilizers & $\begin{array}{c}\text { Protectio } \\
\text { n levels }\end{array}$ & & & & & \\
\hline \multirow{3}{*}{$\begin{array}{l}\text { Without } \\
\text { fertilizers }\end{array}$} & $1^{*}$ & - & - & - & - & - \\
\hline & 2 & - & - & - & - & - \\
\hline & 3 & - & - & - & - & - \\
\hline \multirow{3}{*}{$\mathrm{N}_{60} \mathrm{P}_{60} \mathrm{~K}_{60}$} & 1 & 1.68 & 27636 & 15391 & 1.80 & 9161 \\
\hline & 2 & 2.04 & 33558 & 18580 & 1.81 & 8149 \\
\hline & 3 & 2.11 & 24710 & 19590 & 1.77 & 7931 \\
\hline \multirow{3}{*}{$\begin{array}{c}\text { Manure } 40 \\
\text { t/ha - } \\
\text { background }\end{array}$} & 1 & 1.09 & 17931 & 22593 & 0.79 & 20728 \\
\hline & 2 & 1.29 & 21221 & 24932 & 0.85 & 16295 \\
\hline & 3 & 1.38 & 22701 & 26048 & 0.87 & 14970 \\
\hline \multirow{3}{*}{$\begin{array}{l}\text { Backgroun } \\
\quad \mathrm{d}+ \\
+\mathrm{N}_{60} \mathrm{P}_{60} \mathrm{~K}_{60}\end{array}$} & 1 & 1.86 & 30597 & 33148 & 0.92 & 17822 \\
\hline & 2 & 2.31 & 38000 & 36815 & 1.03 & 14437 \\
\hline & 3 & 2.43 & 39978 & 38091 & 1.05 & 13653 \\
\hline
\end{tabular}

* Note. Plant protection levels: 1 - seed etching; 2 - is the same as $1+$ herbicide + fungicides; 3 - same as $2+$ insecticides + growth substances 


\section{Conclusion}

Studies carried out in long-term field stationary experience have shown that the nutritional regime of blackness typical during vegetation of crops, clogging of crops, productivity of winter wheat, crop structure involved in the experiment, economic and bioenergy indicators are influenced by fertilizers and plant protection means, the statistical reliability of which is determined by the peculiarities of resources, their importance for the studied objects and variability in time and space.

\section{Summary}

1. The greatest increase in nitrate content in the soil layer of $0-10 \mathrm{~cm}$ during sprouting was due to the use of a combination of mineral fertilizers in the dose of $\mathrm{N}_{60} \mathrm{P}_{60} \mathrm{~K}_{60}$ and manure in the dose of $40 \mathrm{t} / \mathrm{ha}(37.1 \%)$ under winter wheat, slightly less - the application of mineral fertilizers in the dose of $\mathrm{N}_{60} \mathrm{P}_{60} \mathrm{~K}_{60}(25.9 \%)$ and the least - the use of manure only in the dose of $40 \mathrm{t} / \mathrm{ha}$ (4.3\%). For mobile phosphates, these parameters were $98.2,97.3$ and $3.2 \%$, respectively, and for exchange potassium, 27.7, 16.6 and $4.1 \%$. The maximum nitrate content noted in the studies $-12.68 \mathrm{mg} / \mathrm{kg}$ soil - was significantly lower than the level of MPC in the soil by $\mathrm{NO}_{3}-130 \mathrm{mg} / \mathrm{kg}$ (Hygienic Standards GN 2.1.7.2041-06, No. CAS 14797-55-8) and cannot pose a danger to plants, animals and humans.

2. Mineral fertilizers in the dose of $\mathrm{N}_{60} \mathrm{P}_{60} \mathrm{~K}_{60}$ contributed to the reduction of clogging of winter wheat crops by $16.3 \%$, their combination with $40 \mathrm{t} / \mathrm{ha}$ manure - by $10.0 \%$, application of only 40 t/ha manure - by $7.4 \%$, and in crops without fertilizers it decreased by $4.2 \%$. Herbicide efficacy increased from $83.9-85.7 \%$ in fertilizer-free crops to 88.5 $92.6 \%$ in different fertilizer systems. The follow-up of herbicidal treatments carried out earlier in crop rotation was $29.6-46.0 \%$.

3 . The maximum yield of winter wheat was $5.52 \mathrm{t} /$ ha using the organic-mineral fertilizer system according to the third level of plant protection, in which the whole complex of chemical agents was used: mineral fertilizers, manure, seed etching, herbicides, fungicides, insecticides, growth substances with the highest payback of $1 \mathrm{~kg}$ of mineral fertilizers with a crop increase of $15.5 \mathrm{~kg}$. The productivity increase from joint effect of mineral fertilizers in a dose of $\mathrm{N}_{60} \mathrm{P}_{60} \mathrm{~K}_{60}$ and manure in a dose of $40 \mathrm{t} / \mathrm{ha}$ at the $1 \mathrm{st}$ level of protection of plants (a treatment a seed) made $1.86 \mathrm{t} / \mathrm{ha}(68.1 \%)$, at the 2 nd level of protection (a treatment a seed herbicides fungicides) - $2.55 \mathrm{t} / \mathrm{ha}(93.4 \%)$ and at the $3 \mathrm{rd}$ level of protection (a treatment of seeds herbicides fungicides insecticides growth substances) - $2.79 \mathrm{t} / \mathrm{ha}$ $(102.2 \%)$. The highest increase from pesticides at the $2 \mathrm{nd}$ and $3 \mathrm{rd}$ levels of protection in the organic-mineral fertilizer system, respectively, was 0.69 and $0.93 \mathrm{t} / \mathrm{ha}(15.0$ and $20.3 \%)$.

4. Organic-mineral fertilizer system to a greater extent than other systems provided a tendency to increase grain nature (13-16 g/l).

5. According to the increase of gluten content in the grain of the fertilizer system, the following descending row is located: organic-mineral (3.8-5.3\%), mineral (2.6-3.3\%) and organic $(2.1-2.5 \%)$.

6. The most significant increase in raw protein content in grain is due to the use of mineral fertilizer system $(2.0 \%)$.

Protein collection, as an integral indicator of yield and quality of production, proved to be almost equal in the application of mineral fertilizer system $-\mathrm{N}_{60} \mathrm{P}_{60} \mathrm{~K}_{60}-643 \mathrm{~kg} / \mathrm{ha}$ and organic-mineral system $-\mathrm{N}_{60} \mathrm{P}_{60} \mathrm{~K}_{60}$ in combination with $40 \mathrm{t} / \mathrm{ha}$ manure $-646 \mathrm{~kg} / \mathrm{ha}$. The increase in protein collection was 315 and $318 \mathrm{~kg} / \mathrm{ha}$, respectively (96.0 and $97.0 \%$ ).

7. The largest number of productive stems of winter wheat was observed in the application of organic-mineral fertilizer system with the 3rd level of protection - 462 piece/sq.m. 
8. The height of winter wheat plants increased significantly with the application of mineral fertilizers and their combinations with manure.

9. A significant increase in the mass of 1000 grains $\left(\operatorname{LED}_{05}=1.20 \mathrm{~g}\right)$ caused mineral fertilizers in the dose of $\mathrm{N}_{60} \mathrm{P}_{60} \mathrm{~K}_{60}$ using the $3 \mathrm{rd}$ level of plant protection (1.29 g). The combined application of mineral fertilizers and manure at a dose of $40 \mathrm{t} / \mathrm{ha}$ contributed to a significant increase in the weight of zeroes at the 2nd and 3rd levels of protection (1.44 and $1.48 \mathrm{~g}$, respectively).

10. The largest mass of zeroes from one wheel was at the 2 nd and 3rd levels of protection using mineral and organo-mineral fertiliser systems - 1.11-1.13 g. At the same time, its increase with increasing intensity of protection means application from the 1 st to the 2 nd level is characterized as significant, and from the 2 nd to the $3 \mathrm{rd}$ as a weak trend.

11. The use of mineral fertilizers in the dose of $\mathrm{N}_{60} \mathrm{P}_{60} \mathrm{~K}_{60}$ is bioenergically justified, as the energy involved in the crop increase exceeds the energy costs from the use of fertilizers, and the energy coefficient (coefficient energy efficiency, $\mathrm{C}_{\mathrm{ee}}$ ) exceeded 1.0 and amounted to $1.80,1.81$ and 1.77 , respectively, 1,2 and 3 levels of protection at energy consumption per unit of grain yield increase 9161,8149 and $7931 \mathrm{MJ} / \mathrm{t}$.

At the 2nd and 3rd levels of plant protection, the use of an organic mineral fertilizer system $\left(\mathrm{N}_{60} \mathrm{P}_{60} \mathrm{~K}_{60}\right.$ manure of $\left.40 \mathrm{t} / \mathrm{ha}\right)$ is justified, where the energy coefficient was 1.03 and 1.05. Even the use of herbicides, fungicides, insecticides and growth substances in the plant protection system did not produce a bioenergically sound crop increase from manure when $\mathrm{C}_{\mathrm{ee}}=0.87$. When designing a fertilizer system for the planned crop increase, it is necessary to take into account the energy consumption not exceeding $14437 \mathrm{MJ} / \mathrm{t}$ of the increase, as if it is exceeded, bioenergetic expediency will not be observed $\left(\mathrm{C}_{\mathrm{ee}}<1\right)$.

\section{The research carried out make it possible to make following offers to production}

1. In the south-west of the CBR, under conditions of unstable moisturization on black-soil typical for the purpose of preservation and increase of soil fertility and obtaining high yields of winter wheat with good quality indicators, it is necessary to design an organicmineral fertilizer system in cultivation technology, including mineral fertilizers at a dose of $\mathrm{N}_{60} \mathrm{P}_{60} \mathrm{~K}_{60}$ and manure at a dose of $40 \mathrm{t} / \mathrm{ha}$.

2. The fertilizer system for the planned crop increase should be oriented to a value of energy consumption not exceeding 14437 MJ per $1 \mathrm{t}$ of the increase due to bioenergy feasibility.

3. The design of an organic fertilizer system using manure only does not seem appropriate because it does not meet the requirements of bioenergy efficiency at all levels of plant protection $\left(\mathrm{C}_{\mathrm{ee}}=0.79-0.87\right)$.

4. The norm of winter wheat seeds sowing is established on the basis of the calculation of production stems number $440-460$ piece/sq.m. by the harvest period, which ensure optimal conditions of productivity formation in agrocenosis.

\section{References}

1. V. Bhaskar, European Journal of Agronomy 105, 86-95 (2019) doi.org/10.1016/j.eja.2019.01.008

2. P. Bilsborrow, European Journal of Agronomy 51, 71-80 doi.org/10.1016/j.eja.2013.06.003

3. H. Chen, The Crop Journal 6, 589-599 (2018) doi.org/10.1016/j.cj.2018.06.002 
4. J. Burger, European Journal of Agronomy 40, 54-63 (2012) doi.org/10.1016/j.eja.2012.02.001

5. V. Fantin, Journal of Cleaner Production, 140(2), 631-643 (2017) doi.org/10.1016/j.jclepro.2016.06.136

6. S.-K. Lammoglia, Environment International 105, 66-78 (2017) doi.org/10.1016/j.envint.2017.04.012

7. C. Loyce, Field Crops Research 125, 167-178 doi.org/10.1016/j.fcr.2011.08.007

8. A. Maltas, Soil and Tillage Research 126, 11-18 (2013) doi.org/10.1016/j.still.2012.07.012

9. M. Mazzoncini, Food Chemistry 175, 445-451 doi.org/10.1016/j.foodchem.2014.11.138

10. Z. Si, Agricultural Water Management 231, (2020) doi:10.1016/j.agwat.2020.106002

11. V. Š́p, Soil and Tillage Research 132, 77-85 (2013) doi.org/10.1016/j.still.2013.05.002

12. F. Van Stappen, Agriculture and Agricultural Science Procedia 7, 272-279 (2015) doi:10.1016/ j. aaspro.2015.12.047

13. L. Wang, Agricultural Water Management $229 \quad$ (2020) doi:10.1016/j.agwat.2019.105934

14. E. Wójcik-Gron, Field Crops Research 227, 19-29 (2018) doi.org/10.1016/j.fcr.2018.07.015

15. Hai-cheng $\mathrm{Xu}$, Journal of Integrative Agriculture 17(2), 315-327 (2018) doi.org/10.1016/S2095-3119(17)61805-7 